\title{
(息)
}

Citation:

Martin, K and Dalton, B and Nikolopoulou, M (2013) Art as a Means to Disrupt Routine Use of Space. Journal of Police and Criminal Psychology, 28. pp. 139-149. ISSN 0882-0783 DOI: https://doi.org/10.1007/s11896-013-9130-1

Link to Leeds Beckett Repository record:

https://eprints.leedsbeckett.ac.uk/id/eprint/4814/

Document Version:

Article (Accepted Version)

The aim of the Leeds Beckett Repository is to provide open access to our research, as required by funder policies and permitted by publishers and copyright law.

The Leeds Beckett repository holds a wide range of publications, each of which has been checked for copyright and the relevant embargo period has been applied by the Research Services team.

We operate on a standard take-down policy. If you are the author or publisher of an output and you would like it removed from the repository, please contact us and we will investigate on a case-by-case basis.

Each thesis in the repository has been cleared where necessary by the author for third party copyright. If you would like a thesis to be removed from the repository or believe there is an issue with copyright, please contact us on openaccess@leedsbeckett.ac.uk and we will investigate on a case-by-case basis. 


\section{Art as a Means to Disrupt Routine Use of Space}

Karen Martin ${ }^{1}$, Ben Dalton ${ }^{2}$, and Marialena Nikolopoulou ${ }^{1}$

${ }^{1}$ CASE, Kent School of Architecture

University of Kent

Canterbury, UK

k.martin-409@kent.ac.uk,m.nikolopoulou@kent.ac.uk

${ }^{2}$ Faculty of Art, Environment \& Technology

Leeds Metropolitan University

Leeds, UK

b.dalton@leedsmet.ac.uk

Suggested running head: "Art as a Means to Disrupt"

J Police Crim Psych (2013) 28:139 - 149

DOI 10.1007/s11896-013-9130-1

Published online: 27 June 2013

(C) Springer Science+Business Media New York 2013 


\title{
Art as a Means to Disrupt Routine Use of Space
}

\begin{abstract}
This paper examines the publicly visible aspects of counter terrorism activity in pedestrian spaces as mechanisms of disruption. We discuss the objectives of counter terrorism in terms of disruption of routine for both hostile actors and general users of public spaces, categorising the desired effects as 1) triangulation of attention; 2) creation of unexpected performance; and 3) choreographing of crowd flow. We review the potential effects of these existing forms of disruption used in counter terrorism. We then present a palette of art, advertising, architecture, and entertainment projects that offer examples of the same disruption effects of triangulation, performance and flow. We conclude by reviewing the existing support for public art in counter terrorism policy, and build on the argument for art as an important alternative to authority. We suggest that while advocates of authority-based disruption might regard the playfulness of some art as a weakness, the unexpectedness it offers is perhaps a key strength.
\end{abstract}

Key words: art, terrorism, counterterrorism, routine, disruption, play, authority 


\section{Introduction}

Many counter terrorism policies have adopted an overt, publicly visible, authorityfocused component alongside the largely covert strategies of surveillance, securing potential targets and infiltration of organised terrorist group. This paper argues that there are key flaws in overt displays of authority, control or militaristic security in 'target hardening' and deterrence, and proposes long-established approaches of public art, performance and urban play as equally, if not more, effective alternatives to the identified goals of visible counter terrorism in public spaces. We discuss counter terrorism in terms of disruption, and argue that while art could be seen as less potent than displays of authority because of its playfulness, the unexpectedness of play is actually a key strength of art in designing safer spaces.

We are primarily concerned here with the publicly visible performance of 'target hardening' policy and counter terrorism activities in pedestrian spaces. The permanent physical infrastructures of counter terrorism activities have already undergone some review in relation to public perceptions of authority. For example, one possible response to threat in a publicly accessible space is to restrict situational opportunities for crime (Clarke, 1997). This approach of target hardening is seen in the construction of the 'ring of steel' fortifications, established around the City of London following the Bishopsgate bombing in 1993 (Coaffee et al., 2009) and in the sunken paths encircling the Washington Monument, Washington DC (Benton-Short, 2007). Authority-focused responses can be disorientating and threatening for other people so diminishing the quality of experience of a space (Benton-Short, 2007). Recent strategies for securing public space have shifted from such overt security measures to less conspicuous responses such as the manipulation of form, materials and configuration to create spaces, spatial features and street furniture that intend to 
influence people's movement and emotional state ( Coaffee et al., 2009) (Adey, 2008). It is worth noting that the publicly visible facet of permanent surveillance infrastructure (Németh, 2010) plays a part in a wider set of temporary and permanent overt displays of observation. It is argued that target hardening in counter terrorism causes terrorist activity to be tactically and geographically displaced rather than removing a threat (Fussey, 2007). The prevalence of target hardening in light of this suggests an ongoing desire to deter attacks from particularly symbolic targets, or in the spaces controlled by well organised or funded security (Coaffee, 2010).

A particular focus is taken in this paper on the temporary aspects of target hardening and deterring hostile reconnaissance. Counter terrorism activity manifests in public view as an ongoing programme of security communication within a wide range of 'potential target' spaces. These include ports of entry, crowded transport, shopping areas, busy events and tourist destinations (e.g., Home Office, 2012). The publicly visible aspects of counter terrorism are framed with a number of objectives including dissuading or drawing attention to those conducting reconnaissance and dry runs, and motivating other users of these spaces to assist in identifying and reporting behaviour of concern. Pre-emption strategies such as the deployment of armed police guards, controlled access points and scanning technologies (Benton-Short, 2007; Adey, 2004) often have a multiplicity of purposes, seeking to simultaneously protect and reassure users of a space, encourage vigilance from the general public, disrupt those engaged in covert activities and elicit noticeable behaviour (Németh, 2010; Coaffee et al., 2008). Publicly visible counterterrorism actions may also form part of a macro level display of security activity, either with political motivations or with the intention of making a country or region as a whole comparatively less desirable for attackers (Coaffee, 2010). 
Temporary publicly salient counter terrorism activity can take on a number of forms, from the deployment of high-visibility armed policing, to announcements drawing attention to security cameras, to posters asking members of the public to report suspicious activity. The aims of these activities seem to fall broadly in to two approaches. The first is activity aimed directly at those planning or attempting to carry out a terrorist attack. These can take the form of demonstrations of security aimed at disrupting pre-attack activity, provoking identifiable reactions from those conducting reconnaissance, or deterring those planning an attack from choosing a particular site (Németh, 2010). While aimed at a specific known or predicted individual or group threat, these performances in public have a wider audience of users of the space. The second set of activities are those aimed at engaging the public in aiding the detection of 'out of place' behaviour that may indicate the planning or carrying out of an attack, or aimed at fostering a sense of personal responsibility for security (Coaffee et al., 2008; Fussey, 2007). While primarily addressed to the general population of a space, these activities may also be a statement to those planning an attack that such a space is under active and wide-reaching attention.

It is useful to consider the approaches outlined above, both those speaking to specific threats and those addressing wider publics, as mechanisms of disruption. In the case of communication to hostile actors, the apparent aim is to disrupt reconnaissance, disrupt preparation activity or disrupt the attempts by an individual or group to hide their intentions. In the case of the other users of a space, the disruption is, it seems, often a means of trying to elicit behaviours of heightened awareness and observation, or of compliance.

In this paper we will first categorise existing publicly visible counter terrorism into three broad forms of disruption effect: triangulation, performance and flow. We 
then present a palette of alternatives for designing disruption in the same three categories. Finally we return to counter terrorism policy to make the case for why we advocate adopting approaches to public space disruption through art, rather than disruption approaches grounded in a context of authority.

\section{The Effects of Disruption in Publicly Visible Counter Terrorism}

\subsection{Triangulation}

The role of 'informal' surveillance through public observation and reporting reoccurs as an objective in publicly visible counter terrorism strategies. Managers of security often respond to increased threat levels by encouraging members of the public to increase their vigilance and report anything that appears suspicious (Coaffee et al., 2008) - employing what Hillier calls 'natural policing' (Hillier, 2004). This builds on the broad literature on crime prevention through environmental design, extending concepts of 'natural surveillance' from Jacobs (1961) and Newman (1972) to the context of counter terrorism. For example in the UK, Project Griffin cites a key objective to "empower people to report suspicious activity and behaviour" (City of London Police, 2004, para. 3). Reoccurring design approaches towards this goal are communication campaigns intended to encourage the people to be more observant and to discuss their concerns (Triggs \& McAndrew, 2009). The US Department of Homeland Security "If You See Something, Say Something” poster campaign, started in 2010, is a good example of publicly positioned visual design intended to foster heightened attention from passengers to those around them and subsequent communication of their concerns (Department of Homeland Security, 2010). In his analysis of public spaces, Whyte (1988) describes this "process by which some external stimulus provides a linkage between people and prompts strangers to talk to 
each other as if they were not" (p. 154) as 'triangulation'. Triangulation can be understood as a temporary disruption of a state of 'civil inattention'. Civil inattention is a strategy for managing routine co-presence in public spaces characterised by the acknowledgement of others, followed by deliberate minimization of contact (Goffman, 1966). Triangulation offers a framework to understand existing counter terrorism signage, announcements and security, and begins to suggest the ways in which alternative design approaches could support heightened awareness and reporting.

\subsection{Performance}

Initiatives such as BASS (Behaviour Analysis Screening System), in the UK, and SPOT (Securing Passengers by Observation Techniques), in the US, train security staff to identify suspicious behaviour and body language in response to temporary, high-visibility disruption of spaces (Edwards, 2010). These interventions appear to raise levels of discomfort with the goal of eliciting behavioural cues that help security staff identify people who have something to hide.

The UK counter-terrorism security design guide for the built environment Protecting Crowded Places includes discussion of the role a visible security regime can play to "deter, detect and delay" suspicious terrorist activity including hostile reconnaissance (Home Office, 2012). The guide describes a case study example of an 'archway metal detector' outside a single entry point to a crowded venue, with staff in high visibility jackets and signs highlighting partnership with the police. The guide concludes:

It very effectively advertises that there is a well-managed and stringent security regime in place and is a potential deterrent to a large amount of 
criminal activity, including hostile reconnaissance ... (Home Office, 2012, p. 39)

The disruption that an impression of effective searches and metal detectors may have on the carrying out of an attempted attack is clear. The effect these measures have on deterring hostile reconnaissance is less well defined, but could include raising the stakes for an individual trying to maintain a constructed inconspicuous identity or heightening the risk of revealing concealed reconnaissance materials like a specialist map or hidden camera. The archway metal detector is one of several security interventions that require pedestrians to 'perform' in public view. For someone conducting hostile reconnaissance, the deterrence seems to lie in the performance of normality required of them, which might evoke fears that their covert intentions will be 'found out' at this pinch point of scrutiny. We can look to literature on lying and deception to understand this aspect of disruption and performance.

De Paulo et al. (2003) suggest that liars and truth tellers share the same goal, that is, to appear honest. Granhag et al. (2004) argue that liars awaiting interview tend to prepare for this performance of honesty by planning their responses in greater detail than truth tellers do. The 'unexpected questioning' approach to detecting liars and truth tellers of Vrij et al. (2009) builds on this hypothesis and proposes that when liars are presented with questions they have not anticipated they will struggle to answer them. Thus, asking for information to be presented in unexpected ways, for example requiring interviewees to tell their story in reverse chronological order, may elicit cues to deception that enable observers to distinguish liars' responses from those of truth-tellers (Vrij et al. 2009; Liu et al. 2010).

Vrij et al. (2009) suggest that a possible explanation for the success of the unexpected questioning approach is that it increases cognitive load. Unexpected 
public disruptions that evoke performance may similarly increase cognitive load for individuals engaged in covert activities. For example, Project Griffin, a joint partnership between the London police, Metropolitan police and private sector security, aims to disrupt hostile reconnaissance activity through intervening in public space using temporary cordons and high visibility patrols (Coaffee et al., 2008).

\subsection{Flow}

Perceived surveillance was found to deter people from carrying out crimes in specific sites (Brantingham \& Brantingham, 1993). In the case of many terrorist activities however, the effect is less conclusive. Fussey (2007) notes that the presence of widespread visible CCTV in London had no noticeable effect on the suicide bombing of the mass transit systems in 2005 , and yet deterrence is often cited as benefit of CCTV for counter terrorism. In Counter Terrorism Protective Security Advice for Stadia and Arenas the National Counter Terrorism Security Office (NaCTSO, 2011) state that "Effective CCTV systems can help prevent or even deter hostile reconnaissance" (p. 41). One of the arguments made for surveillance infrastructure is that publicly visible security protocols can be used to potentially manipulate the spatial aspects of hostile reconnaissance, delaying or deterring activity in the planning stages of an attack. For example one guide to 'protective intelligence' (Stratfor, 2010) gives the example of using overt displays of security as a means of 'heating up' key locations to move potential hostile reconnaissance away from one area and in to other areas where covert surveillance may be concentrated. More broadly, the control or shaping of pedestrian movement reoccurs as an aspect of security planning for crowded spaces. Physical and social characteristics of a space are inter-dependent, and changes to one element will elicit change in the other (Hillier \& Sahbaz, 2009). 
Physical barriers are used to shape crowd flow particularly in airports, stations and sports events. Adey (2008) describes how airport designers manipulate form, materials and configuration to elicit specific emotions and to direct passengers' movement around airport departure areas. It may also be desirable for sight lines to key covert security features to be controlled or blocked, either permanently or temporarily.

A broader review of experimental evidence of techniques for shaping pedestrian movement can be found in the advertising and marketing literature of shopping behaviour. In particular, a number of studies have used 'approach-avoidance' as a dependent variable, with Mehrabian and Russell (1974) establishing pleasure, arousal and dominance or 'personal control' as relevant emotional states. More recent studies have shown that pleasure has the strongest influence on 'approach' (Chebat, 1995), and that personal control is correlated with pleasure and negatively correlated with crowding (Bateson \& Hui, 1987; Hui \& Bateson, 1991). Criminology literature also discusses influencing personal control, Brantingham and Brantingham (1993) describe how people carrying out crime develop a 'crime template' or idealized site for their criminal act and then try to match this location with places they already know or those that they come into contact with. They suggest that a criminal's ideal crime location is one where they are comfortable and feel that they fit in. By intervening at the point where situational aspects of covert activity converge, that is the times and places where the actors, location and opportunity for criminal endeavours overlap, the intended action can be interrupted (Cornish, 1994). Within the context of counter terrorism in public places, this suggests a particularly strong effect on flow for disruptions that heighten crowd pleasure (approach), while reducing feelings of control in those conducting hostile reconnaissance (avoidance). 


\section{Means of Disruption: A Palette of Art Interventions}

\subsection{Triangulation}

We should begin our discussion of art as a means of disruption by returning to Whyte's (1980) study of small urban spaces, in which he describes the addition of sculpture to public space and its effect on pedestrian flow, performance and triangulation:

Sculpture can have strong social effects. Before and after studies of the Chase Manhattan plaza showed that the installation of Dubuffet's "Four Trees" has had a beneficent impact on pedestrian activity. People are drawn to the sculpture, and drawn through it: they stand under it, beside it; they touch it; they talk about it. At the Federal Plaza in Chicago, Alexander Calder's huge stabile has had similar effects. (p. 96)

Techniques of interaction and reflection in art are well suited to the objectives of triangulation. The ability of art to catch the attention of members of the public and draw them in to states of heightened awareness and discussion seem to embody the objectives of "If You See Something, Say Something" counter terrorism strategies. For example, Wooden Mirror by Daniel Rozin (1999) is an artistic work that presents viewers with a distorted image of themselves. In this installation the individual's image is reflected back to them through changes in position of articulated wooden panels. Rozin (n.d.) is interested in the point where the viewer and the work converge, describing this as an interface or "some sort of membrane between you and the experience” (p. 2). Rozin (n.d.) suggests that despite Wooden Mirror's unusual material "you understand immediately that it's a mirror, you know how to operate it, and no interface is involved" (p. 2). Similarly, mirrors were one of the materials used 
by Olafur Eliasson (2003) to create The Weather Project, an installation that transformed the Turbine Hall of Tate Modern into an atmospheric and social space. This physical transformation of the space elicited a change in how visitors behaved in the gallery, with people sitting or lying on the floor to view themselves, and each other, in the overhead reflections. Ione (2008) suggests that Eliasson is interested in displacing the viewer's sense of self in relation to the space with the intention to stimulate communication.

$<$ Fig 1 about here $>$

Technology in art can allow for the disruptive effects of sculpture to be temporarily added to a space comparatively cheaply and quickly. For example, the video installation Body Movies by Rafael Lozano-Hemmer (2001) uses light and shadows to elicit participation and collaboration. In this artwork large shadows of the occupants are projected onto the walls with video recorded clips being revealed inside these dark silhouettes.

$<$ Fig 2 about here $>$

Body Movies is designed for installation in town squares and other, similarly open, populated spaces, and addresses the ambiguous relationship between seeing and being seen. Lozano-Hemmer (cited in Adriaansens et al., 2002) suggests that participation with the intervention is multi-layered:

... on the one hand you can have the discrete individual participation, as one's shadow is recognizably one's own; but there are also emerging collective 
patterns of self-organization, as people may choose to interact with one another, with the building or with the portraits. (p. 4)

While shadows may seem more difficult to associate with actual persons than mirror reflections, Snibbe and Raffle (2009) find that people quickly recognise their own shadows and those of people they know. With both mirrors and shadows the responsiveness of the display to people's movements, and people's ability to find their own shadow on the screen, creates a junction of viewer and space, disrupting civil inattention and raising awareness of the activities and persons around them. The finding that people recognise their own shadow and those of people they know, suggests that shadows and silhouettes have the ability to provide identifiable representations while preserving an individual's anonymity in the crowd. We advocate that this property is appropriate for creating interventions that seek to raise an individual's sense of self-awareness in a space while maintaining a relaxed atmosphere for the general public.

\subsection{Performance}

In addition to fostering triangulation, elements of interaction and reflection found in mirrors and shadows in public art demonstrate a strong ability to encourage performance from audiences. In the context of deterring hostile reconnaissance, we are interested in art that creates physical examples of 'unexpected questioning' through playful disruption or a heightened sense of being on view. Whyte (1980) gives the example of street entertainment:

Musicians and entertainers draw people together ... however, the real show is usually the audience. Many people will be looking as much at each other as at what's on the stage. (p. 97) 
In Shadow Monster by Philip Worthington (2005) the simple casting of shadows on a wall is given an unexpected twist as the shadows are augmented with the addition of teeth, legs and other monster-like appendages engaging passers-by with a constantly changing façade that responds to their actions.

$<$ Fig 3 about here $>$

The playful, computational additions to the shadows in Shadow Monster add an unexpected aspect to these representations that appears to intrigue and amuse participants and bystanders (Worthington, 2005). We believe that these computational additions render the space surprising and playful and that this has the potential to interrupt routine behaviour as people stop to observe or interact with the intervention. In addition, the large-scale nature of the installation offers potential for people to collaborate to perform elaborate shadow plays. In this way Shadow Monsters creates opportunities for an almost endlessly changing visual environment through interaction with co-present persons and the properties of the computer system.

Turning the World Upside Down is an artwork created by Anish Kapoor (2010) and set in Kensington Gardens, London. The work is comprised of a series of extravagantly shaped and polished steel mirrors that present a distorted view of the environment to spectators.

$<$ Fig 4 about here $>$

Kapoor (cited in Bhabha, 1998) states that in creating these works he is interested in exploring "that condition that seems to be abidingly static and at the same time 
dynamic ... it's the effect of an enormous weight ... out of balance.” (p. 26). Puwar (2004) argues that Kapoor treats this psychological state of instability as a productive moment that evokes feelings of disorientation or dislocation for the viewer. Bhabha (1998) suggests that when a spectator stands before Kapoor's work the emotions created by this unstable instance of pause are "anxiety, unease, restlessness". A clear analogy can be drawn to the authority-focused interventions such as Project Griffin and BASS.

We have seen that overt surveillance is often cited as a deterrent to hostile reconnaissance. Surveillance that encourages performance can be seen as an effective form of 'heating up' a location as discussed earlier. In art and architecture we find numerous examples of work that performatively draws attention to CCTV. The architects Diller and Scofidio (cited in Levin et al., 2002) write "Once considered invasive, electronic surveillance is now the accepted social contract in public space, a welcome assurance of security, and a performance vehicle" (p. 355). Diller and Scofidio (2000) explore this social contract in the video installation that forms part of their design for The Brasserie in the Seagram building, New York. In this intervention a snapshot is captured as customers enter the bar from a CCTV camera attached to the revolving door. The images are then displayed on a row of screens positioned above the bar. As a new customer enters their image is placed on the screen at one end of the bar and the oldest image is removed at the other. In this way surveillance technologies are given a playful spin by presenting the captured images back to the occupants of the bar, exploiting the tension between the desire for privacy and attention.

$<$ Fig 5 about here $>$ 
Chris O'Shea's (2009) intervention Hand from Above similarly appropriates surveillance technologies. In this artwork O'Shea interrupts routine behaviour by playing on people's tacit awareness of the ubiquity of video surveillance. Installed on the BBC's Big Screens, Hand from Above appears to show a real-time video feed of the environment in which the screen is located, however, at intervals, a large hand appears on the screen and picks up, or tickles, one of the passers so lifting them out of reality for a few seconds. O'Shea writes “Hand From Above encourages us to question our normal routine when we often find ourselves rushing from one destination to another. ... Passers by will be playfully transformed." (O’Shea, 2009, para. 1).

$<$ Fig 6 about here $>$

O'Shea (2009) has documented a range of responses to Hand from Above; people stop to see what will happen next; they try to avoid the hand or, alternatively, to attract it; and they point out what's going on to the people around them.

ACCESS, by artist Marie Sester (2003), explores further the different responses that being in the spotlight can elicit. In this installation a computer vision system is used to highlight an individual in public space by turning a spotlight on them. The light remains trained on the subject as they move around the space. Once under the spotlight individuals have to choose whether to attempt to evade the tracking system or to submit to being the temporary focus of attention. Writing about this work Donath (2008) notes "Some find the gaze disconcerting, authoritarian-they 
do not wish to be stared at by it or to have attention drawn to themselves. Others see it as the spotlight of celebrity and respond by performing as if on stage" (p. 23).

$<$ Fig 7 about here $>$

\subsection{Flow}

Techniques to disrupt flow aim to shape pedestrian movement and crowds, and to simultaneously influence the movement through a space of those with hostile intent. As discussed, we seek art works that can heighten crowd pleasure to encourage pedestrians to approach a specified location, whilst simultaneously reducing feelings of personal control through disruption of routine for those conducting hostile reconnaissance. In 2007 the urban environment of Trafalgar Square in London was transformed into a green refuge ("Trafalgar Square green", 2007). Re-surfacing the paving slabs of Trafalgar Square with Yorkshire turf sought to interrupt routine behaviour by transforming the physical character of the space. This simple change elicited an array of alternative behaviours including sunbathing, games of golf and picnicking that would previously have appeared out of place. Activities occurred in locations normally not so heavily used.

$<$ Fig 8 about here $>$

Luke Jerram's (2008) artwork Play Me, I'm Yours also explores the use of objects and materials to suggest possible behaviours and ways of interacting at specified locations in public space. For this intervention Jerram placed upright pianos into a number of outdoor sites, 'heating up' empty locations with the invitation to play. 
$<$ Fig 9 about here $>$

The pianos were tuned daily but otherwise left unattended for people to use as they chose. Documentation of the project reveals how the pianos elicited a variety of responses ranging from individual recitals to group sing-a-longs (Jerram, 2008). Subway Swing, by Caroline Woolard (2006), consists of a swing seat and ropes that are unpacked and installed into subway carriages for short periods of time.

$<$ Fig 10 about here $>$

Play Me I'm Yours and Subway Swing are similar in that familiar objects are placed in atypical locations drawing people in, and inviting unprompted, unexpected behaviour and triangulation from members of the public. Similarly, the Weather Project discussed above also elicited collaboration between gallery visitors as they moved about the space and worked together to form patterns and letters that could be read via the reflections in the ceiling mounted mirrors.

In North-South over East-West by Jason Bruges Architects (2010) pedestrian movement across a bridge in London is collected by sensors and re-presented as a flowing pattern of light creating light 'shadows'. While responsive to people's behaviour, using light to indicate patterns of movement is interesting as the designer retains a measure of control over the appearance and affect created by the lights. Bruges (cited in Bullivant \& Castle, 2005) states "I talk about the reactions of the lights as being choreographed, because you can predetermine the light response." (p. 
81). Bullivant and Castle (2005) suggest that in interactive systems of this kind it is the human reaction that is unpredictable.

$<$ Fig 11 about here $>$

Finally, the project Piano Stairs shows how alterations to a physical space can lead to dramatic changes in flow behaviour. In this intervention the stairs at the entrance to a Stockholm subway station were transformed overnight into a keyboard where each step produced a different note (DDB Stockholm, 2009). The escalator adjacent to the stairs was left untouched.

$<$ Fig 12 about here $>$

The following day, as a result of this intervention, passengers altered their routine path to exit the station, with $66 \%$ more people than usual choosing to take the stairs instead of the escalator (DDB Stockholm, 2009).

\section{Art as an Alternative to Authority}

The examples of art as a means of disruption described here offer inspiration for the design of unexpected interventions that can heighten attention, disrupt planned routine and elicit noticeable behaviours. In this paper we have detailed three forms of disruptive effect that both art and authority-focused interventions share, and provided links to literature from advertising, deception and built environment criminology that suggest the potential for measurable effect of the disruption used in counter terrorism. As we will review below, art is already regularly cited in counter terrorism policy 
guidelines as an effective tool in the design of safer spaces. We conclude this paper by discussing the weaknesses of authority-focused disruption, and the additional potential for art to enhance the experience of public spaces. We posit that the playfulness of art may be a factor in the hesitance of its use, and that the existing calls for the use of art in visible counter terrorism need to be strengthened.

The Protecting Crowded Places: Design and Technical Issues guide from the UK Home Office (2012), calls for designers to take care to avoid creating "bland and standardised places" in their efforts to design counter terrorism features in to civic spaces. The guide notes that "it is important to retain or insert positive features that attract people to spaces", suggesting "incorporating public art or locally important features" (p. 9) in to spaces as a way to do this. Designing for Security: Using Art and Design to Improve Security goes further in making the case for the role of art in security design for New York City:

Artists and designers should not hesitate to use aesthetic tools as part of the arsenal of security. Light and color, changes of scale, texture - even creative use of sound or smell, temperature and climate control — can convey a sense of safety and help to engage users, staff, and the public. Site relationships, scale relationships, transparency, and opacity may be appropriated to meet expressive, functional, and security needs.” (Russell et al., 2002, p. 35) Similarly in the broader context of crime prevention, the UK Percent for Art: a review states: "Commissioning bodies argue that good art encourages greater use of public places and increases individuals' sense of security" (Arts Council, 1991, p. 17).

The published guidelines for infrastructure protection, counter terrorism protocol and security communication design reviewed all mention publicly visible acts of security or authority. However, the brevity of the discussions of the effects of 
visibility in comparison with covert activity planning suggests that a positive or neutral effect on public perception from visible security has been assumed. As strategies for securing public space develop in response to the ongoing threat of attack, there is growing awareness of the necessity for security measures to be socially acceptable (Németh, 2010) and for them to not impede the functionality of public spaces that play an important symbolic and social role in urban living (BentonShort, 2007; Coaffee et al., 2008). Overt security has been criticised for heightening tension in the general population of a space unnecessarily, and for fostering a sense of division rather than collaboration between the public and security representatives (Minton, 2009). Jacobs (1961) describes how increasing public awareness and fostering social interaction between occupants can generate a sense of trust and social cohesion leading to a feeling of shared ownership. Architectural theorist Newman (1972) argues that defining space in terms of territorial areas or blocks increases the likelihood that members of the public will challenge perceived illegitimate behaviour by strengthening their feelings of responsibility for the space. Others suggest that this sense of attachment is difficult to achieve in unbounded public spaces such as shopping streets, public parks and transport hubs (Coaffee et al., 2008; LoukaitouSideris et al., 2001). Brown et al. (2004) propose that attempts to reduce crime should pay attention to fostering positive feelings towards a place. The examples presented here illustrate how art and play may be appropriated for security purposes by offering an approach to designing interventions that foster a positive experience in public space for the majority of people, yet offer similar outcomes of more authority-focused responses in encouraging vigilance, disrupting routine and eliciting noticeable behaviour. 
Using play to evoke an increase in social interaction is a powerful approach as playfulness creates a collaborative and positive experience for users of a space mitigating feelings of threat and disorientation. Attempts to preempt potential attacks often seek to eliminate uncertainty by managing risk (Aradau \& Van Munster, 2007). In contrast, play thrives on ambiguity, which can be a powerful resource for designs for public space (Gaver et al., 2003). Play is a form of disruption that people are used to and accept; it forms part of the practice of everyday life (Vannini, 2011) and, in contrast to overt security approaches, play is "permissive, contradictory, light-hearted, loose" (Vannini, 2011, p. 10). The interventions we review here illustrate how artistic, playful, spatial interventions can elicit behavioural changes including shaping flow, encouraging public performance, temporarily disrupting routine behaviour, and encouraging awareness and social interaction between inhabitants (Snibbe \& Raffle, 2009). Vannini (2011) also suggests that play is "simultaneously directed at multiple purposes" (p. 10) and we argue, although created for other purposes, the projects reviewed here illustrate the potential of artistic interventions to enhance the experience of a space for inhabitants using playfulness as an approach to elicit behavioural change. Repurposing seems a key aspect in using art as a means of disruption. Indeed, in light of the problematic history of art movements driven by government-imposed style or form, re-location of existing artworks and open-ended commissioning processes seem advisable for the use of art in counter terrorism.

One of the key stated aims of Project Griffin according to the online mission statement is to "Maintain trust and confidence in the police and other authorities" (City of London Police, 2004). There is a tension in light of the "impossibility of entirely preventing terrorist attacks" (Fussey, 2007, p. 176) between the normalisation of overt security and a long term maintenance of confidence. When an attack occurs, 
any significant show of force associated with ongoing authority-focused means of disruption will appear to have failed, and one could argue that this can also cause broader confidence in the authorities to falter. A constant presence of performances of authority in public space also risks trivializing the impact of necessary, future displays of security strength. Authority is also interpreted within a wider cultural context. Fussey (2007) notes that "overpolicing may foment radicalization" among communities who feel particularly targeted because of a reoccurring, heightened authority presence in the spaces they use.

We posit that the biggest challenge traditional art-based forms of disruption face in adoption for counter terrorism policy is a perception that security must be 'visibly authoritative'. Whether this is to justify the expenditure of covert target hardening (Coaffee, 2010) or the political pressure to have taken a 'tough stance' in light of potential future attacks (Coaffee, 2009). Here, the playfulness and social normality of art could be seen as a potential weakness in policy and funding arguments. Yet, as we have discussed, this playfulness is often one of the key strengths of these examples in amplifying desired disruption effects in public spaces.

In his discussion of the logic of fear in terrorism and counterterrorism Braithwaite (2013) concludes that counter terrorism policy would be well served by "more proactively attempting to improve average participant enjoyment of public spaces" which echoes Whyte's (1980) argument from three decades earlier in favour of the potential for public art and entertainment to effect people in urban spaces, "What I'm suggesting, simply, is that we make places friendlier." (p. 98).

\section{Acknowledgements}


This research is conducted as part of the 'Shades of Grey - Towards a Science of Interventions for Eliciting and Detecting Notable Behaviours' project (EPSRC reference: $\mathrm{EP} / \mathrm{H} 02302 \mathrm{X} / 1$ ). We are grateful to the anonymous reviewers for providing thought-provoking and invaluable feedback on earlier drafts of this paper. 


\section{References}

Adey, P. (2004). Surveillance at the airport: surveilling mobility/mobilising surveillance. Environment and Planning A, 36(8), 1365-1380.

Adey, P. (2008). Airports, mobility and the calculative architecture of affective control. Geoforum, 39(1), 438-451.

Adriaansens, A., \& Brouwer, J. (2002). Alien Relationships with Public Space. In M. Arjen \& J. Brouwer (Eds.), Transurbanism (pp. 139-160). Rotterdam: Netherlands Architecture Institute [NAi].

Aradau, C., \& Van Munster, R. (2007). Governing terrorism through risk: Taking precautions, (un) knowing the future. European Journal of International Relations, 13(1), 89-115.

Arts Council. (1991). Percent for Art: A Review. London.

Bateson, J. E. G., \& Hui, M. K. M. (1987). A model for crowding in the service experience: empirical findings. The services challenge: integrating for competitive advantage. Chicago: American Marketing Association, 85-9.

Benton-Short, L. (2007). Bollards, bunkers, and barriers: securing the National Mall in Washington, DC. Environment and Planning D, 25(3), 424.

Bhabha, H. K. (1998). Anish Kapoor: Making Emptiness. In A. Kapoor, H. K. Bhadha, \& P. L. Tazzi (Eds.), Anish Kapoor (pp. 11-41).

Braithwaite, A. (2013). The Logic of Fear in Terrorism and Counterterrorism. Journal of Police \& Criminal Psychology, 27(1), in press.

Brantingham, P. L., \& Brantingham, P. J. (1993). Nodes, paths and edges:

Considerations on the complexity of crime and the physical environment. Journal of Environmental Psychology, 13(1), 3-28.

Brown, B. B., Perkins, D. D., \& Brown, G. (2004). Incivilities, place attachment and crime: Block and individual effects. Journal of environmental psychology, 24(3), 359-371.

Bullivant, L., \& Castle, H. (2005). 4dspace: interactive architecture. Wiley-Academy.

Chebat, J. C., Gelinas-Chebat, C., Vaninski, A., \& Filiatrault, P. (1995). The impact of mood on time perception, memorization, and acceptance of waiting. Genetic, social, and general psychology monographs.

City of London Police. (2004). Mission. Retrieved May 18, 2011, from http://www.projectgriffin.org.uk/index.php/mission

Clarke, R. V. G. (1997). Situational Crime Prevention: Successful Case Studies. Lynne Rienner Pub.

Coaffee, J. (2010). Protecting vulnerable cities: the UK's resilience response to defending everyday urban infrastructure. International Affairs, 86(4), 939-954. 
Coaffee, J., Moore, C., Fletcher, D., \& Bosher, L. (2008). Resilient design for community safety and terror-resistant cities. Municipal Engineer, 161(2), 103-110.

Coaffee, J., O'Hare, P., \& Hawkesworth, M. (2009). The visibility of (in) security: the aesthetics of planning urban defences against terrorism. Security Dialogue, 40(4-5), 489-511.

Cornish, D. (1994). The procedural analysis of offending and its relevance for situational prevention. Crime prevention studies, 3, 151-196.

Department of Homeland Security. (2010). "If You See Something, Say Something" Campaign. Retrieved November 10, 2012, from http://www.dhs.gov/if-you-seesomething-say-something-campaign

DePaulo, B. M., Lindsay, J. J., Malone, B. E., Muhlenbruck, L., Charlton, K., \& Cooper, H. (2003). Cues to deception. Psychological bulletin, 129(1), 74.

Diller, E., \& Scofidio, R. (2000). Brasserie. Retrieved from http://www.dsrny.com/

Donath, J. (2008). Technological Interventions in Everyday Interaction. Act/React catalog, Milwaukee Art Museum.

Edwards, R. (2010, January 15). Heathrow staff given body language training to spot suspected terrorists. Telegraph.co.uk. Retrieved from http://www.telegraph.co.uk/travel/travelnews/6990006/Heathrow-in-security-alert-astwo-men-arrested-on-flight.html

Eliasson, O. (2003). The Weather Project. Retrieved from http://www.tate.org.uk/modern/exhibitions/eliasson/default.htm

Fussey, P. (2007). Observing Potentiality in the Global City Surveillance and Counterterrorism in London. International Criminal Justice Review, 17(3), 171-192.

Gaver, W. W., Beaver, J., \& Benford, S. (2003). Ambiguity as a resource for design. In Proceedings of the SIGCHI Conference on Human Factors in Computing Systems (pp. 233-240). ACM.

Goffman, E. (1966). Behavior in Public Places. Simon and Schuster.

Granhag, P. A., Andersson, L. O., Strömwall, L. A., \& Hartwig, M. (2004). Imprisoned knowledge: Criminals' beliefs about deception. Legal and Criminological Psychology, 9(1), 103-119.

Hillier, B. (2004). Can streets be made safe? Urban Design International, 9(1), 3145 .

Hillier, B., \& Sahbaz, O. (2009). Crime and urban design: An evidence-based approach. In R. Cooper, G. Evans, \& C. Boyko (Eds.), Designing Sustainable Cities (pp. 163-186). Chichester, UK: Wiley-Blackwell.

Home Office. (2012). Protecting Crowded Places: Design and Technical Issues. Home Office. Retrieved from http://www.homeoffice.gov.uk/publications/counterterrorism/crowded-places/design-tech-issues?view=Binary 
Hui, M. K., \& Bateson, J. E. G. (1991). Perceived control and the effects of crowding and consumer choice on the service experience. Journal of Consumer Research, 174184.

Jacobs, J. (1961). The death and life of great American cities. Random House.

Jason Bruges Architects. (2010). Shortcut. Retrieved from

http://www.jasonbruges.com/projects/uk-projects/shortcut

Jerram, L. (2008). Play Me, I'm Yours. Retrieved from http://www.lukejerram.com/projects/play_me_im_yours

Kapoor, A. (2010). Turning the world upside down. Retrieved from http://www.serpentinegallery.org/2010/03/anish_kapoor.html

Levin, T. Y., Frohne, U., Weibel, P., \& Karlsruhe, Z. für K. und M. (2002). Ctrl [space]: rhetorics of surveillance from Bentham to Big Brother. ZKM Center for Art and Media.

Liu, M., Granhag, P. A., Landstroem, S., Hjelmsaeter, E. R., Strömwall, L., \& Vrij, A. (2010). Can You Remember What Was in Your Pocket When You Were Stung by a Bee?': Eliciting Cues to Deception by Asking the Unanticipated. Open Criminology Journal, 3(1), 31-36.

Loukaitou-Sideris, A., Liggett, R., Iseki, H., \& Thurlow, W. (2001). Measuring the effects of built environment on bus stop crime. Environment and Planning B:

Planning and Design, 28, 255-280.

Lozano-Hemmer, R. (2001). Body Movies. Retrieved from http://www.lozanohemmer.com/body_movies.php

Mehrabian, A., \& Russell, J. A. (1974). An approach to environmental psychology. the MIT Press.

Minton, A. (2009). Ground Control: Fear and happiness in the twenty-first-century city. Penguin.

National Counter Terrorism Security Office [NaCTSO]. (2011). Counter Terrorism Protective Security Advice for Stadia and Arenas. Retrieved from https://vsat.nactso.gov.uk/SiteCollectionDocuments/AreasOfRisk/Stadia\%20and \%20Arenas\%202011.pdf

Németh, J. (2010). Security in public space: an empirical assessment of three US cities. Environment and Planning A, 42, 2487-2507.

Newman, O. (1972). Defensible space: Crime prevention through urban design. New York.

O'Shea, C. (2009). Hand from Above. Retrieved from

http://www.chrisoshea.org/hand-from-above

Olafur Eliasson: San Francisco Museum of Modern Art Exhibition. (2008). Leonardo Electronic Almanac, 16(1), 2-5. 
Piano stairs. (2009). DDB Stockholm. Retrieved from

https://www.youtube.com/watch?v=21Xh2n0aPyw

Puwar, N. (2004). Space invaders: Race, gender and bodies out of place. Berg

Publishers.

Rozin, D. (n.d.). Wooden mirror. Retrieved from

http://labspace.open.ac.uk/file.php/4287/Wooden.pdf

Rozin, Daniel. (1999). Wooden Morror. Retrieved from

http://www.smoothware.com/danny/woodenmirror.html

Russell, J. S., Bershad, D., Felicella, E., Kelly, M., \& Kennedy, E. (2002). Designing for security: Using art and design to improve security. Design Trust for Public Space Art Commission of the City of New York. Retrieved from http://www.designtrust.org/publications/publication_97security.html

Sester, M. (2003). ACCESS. Retrieved from http://www.accessproject.net/index.html

Snibbe, S. S., \& Raffle, H. S. (2009). Social immersive media: pursuing best practices for multi-user interactive camera/projector exhibits. In Proceedings of the 27th International Conference on Human Factors in Computing Systems (pp. 1447-1456). ACM.

Stratfor. (2010). How to Look for Trouble: A Stratfor Guide to Protective Intelligence. CreateSpace.

Trafalgar Square green with turf. (2007, May 24). BBC. Retrieved from http://news.bbc.co.uk/1/hi/england/london/6687089.stm

Triggs, T., \& McAndrew, C. (2009). Transforming policy practice in transport: Is there a space for communication design? In Inclusive Design into Innovation: Transforming Practice in Design, Research and Business. Presented at the Include 2009, London: Royal College of Art.

Vannini, P. (2011). Performing elusive mobilities: ritualization, play, and the drama of scheduled departures. Environment and Planning D: Society and Space, 29, 353-368.

Vrij, A., Leal, S., Granhag, P. A., Mann, S., Fisher, R. P., Hillman, J., \& Sperry, K. (2009). Outsmarting the liars: The benefit of asking unanticipated questions. Law and human behavior, 33(2), 159-166.

Whyte, W. H. (1980). The social life of small urban spaces. Conservation Foundation.

Whyte, W. H. (1988). City: rediscovering the center. Doubleday.

Woolard, C. (2006). Subway Swing. Retrieved from $\mathrm{http}: / /$ carolinewoolard.blogspot.com/2006/10/swing-on-subway.html

Worthington, P. (2005). Shadow Monsters. Retrieved from http://www.worthersoriginal.com/viki/ 


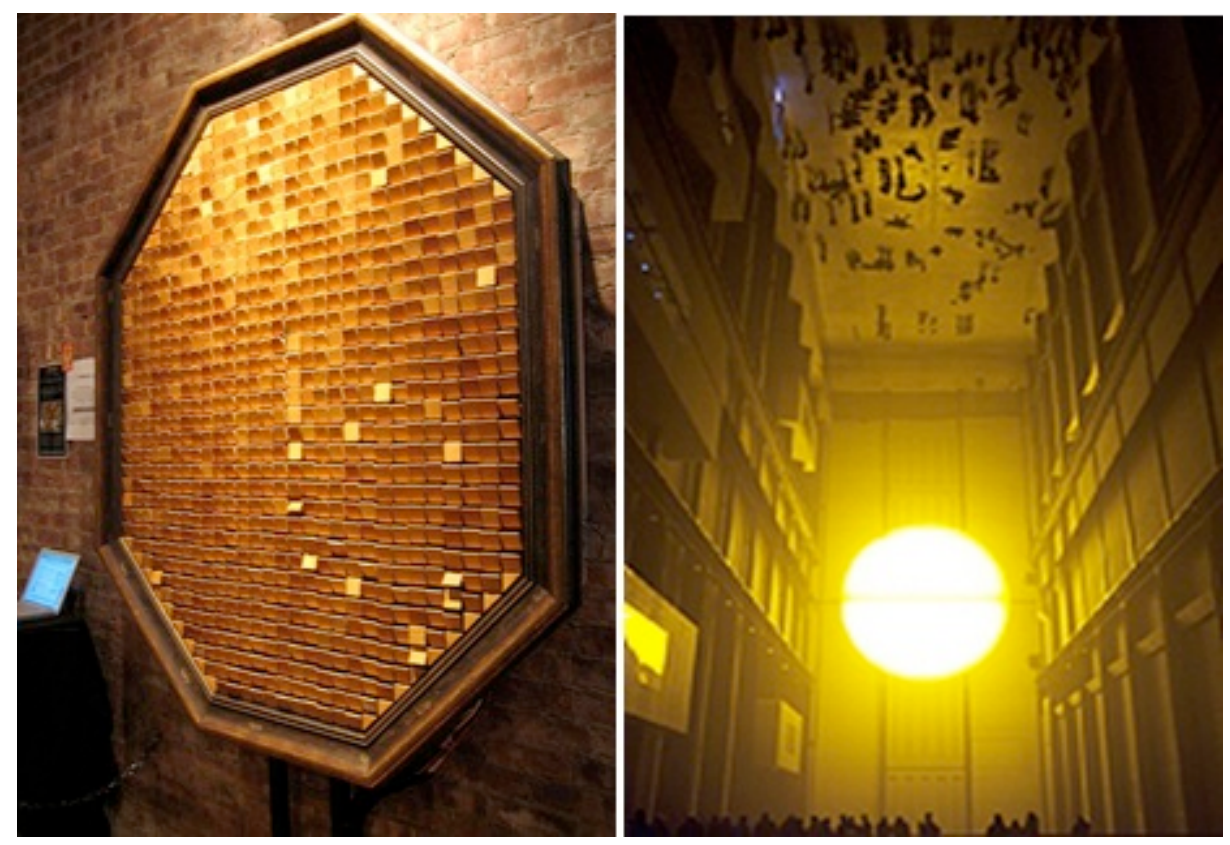

Fig. 1 Wooden Mirror by Daniel Rozin. Photo from Flickr by Roboppy. and The Weather Project by Olafur Eliasson. Photo from Flickr by rjhintz. 


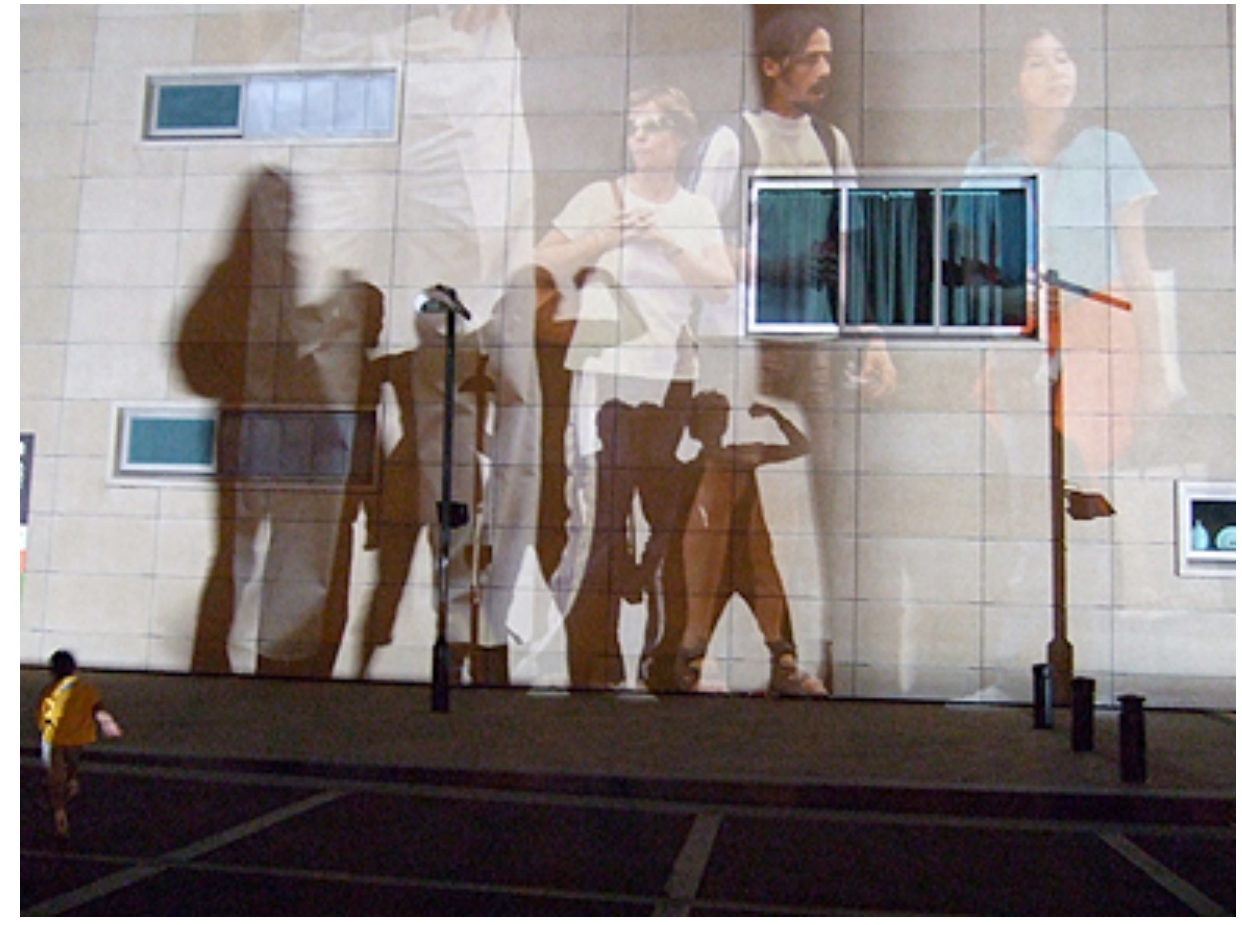

Fig. 2 Body Movies by Rafael Lozano-Hemmer. Photo from Flickr by Kayhadrin. 


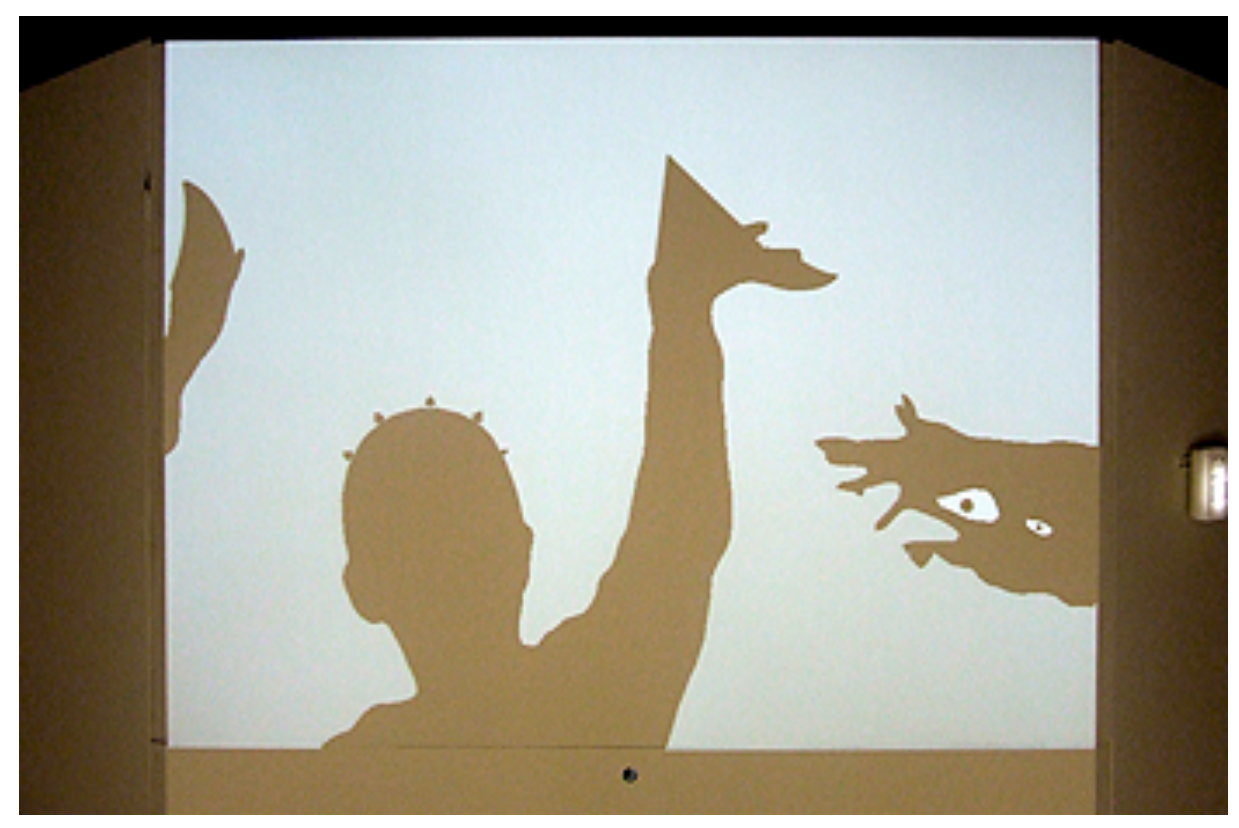

Fig. 3 Shadow Monsters by Philip Worthington. Photo from Flickr by martintom 


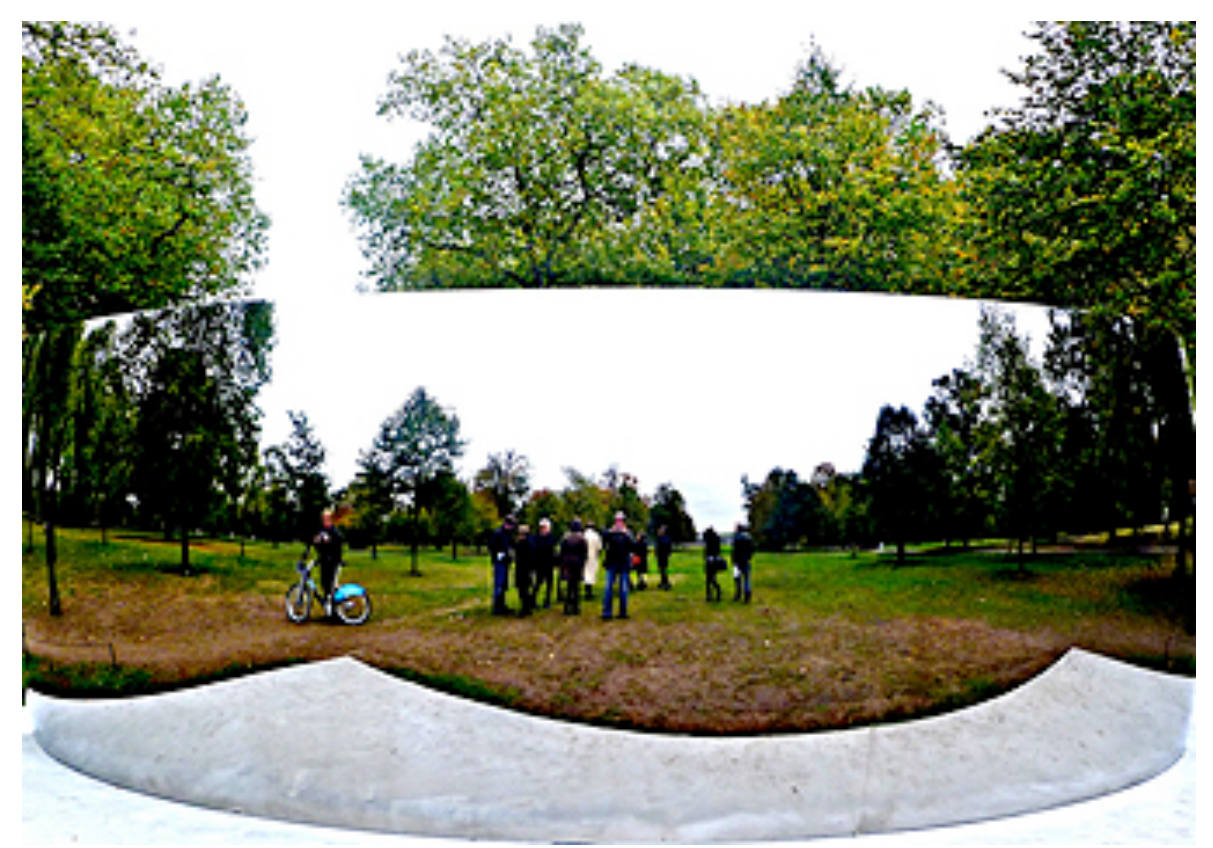

Fig. 4 Turning the World Upside Down by Anish Kapoor. Photo from Flickr by HerryLawford 


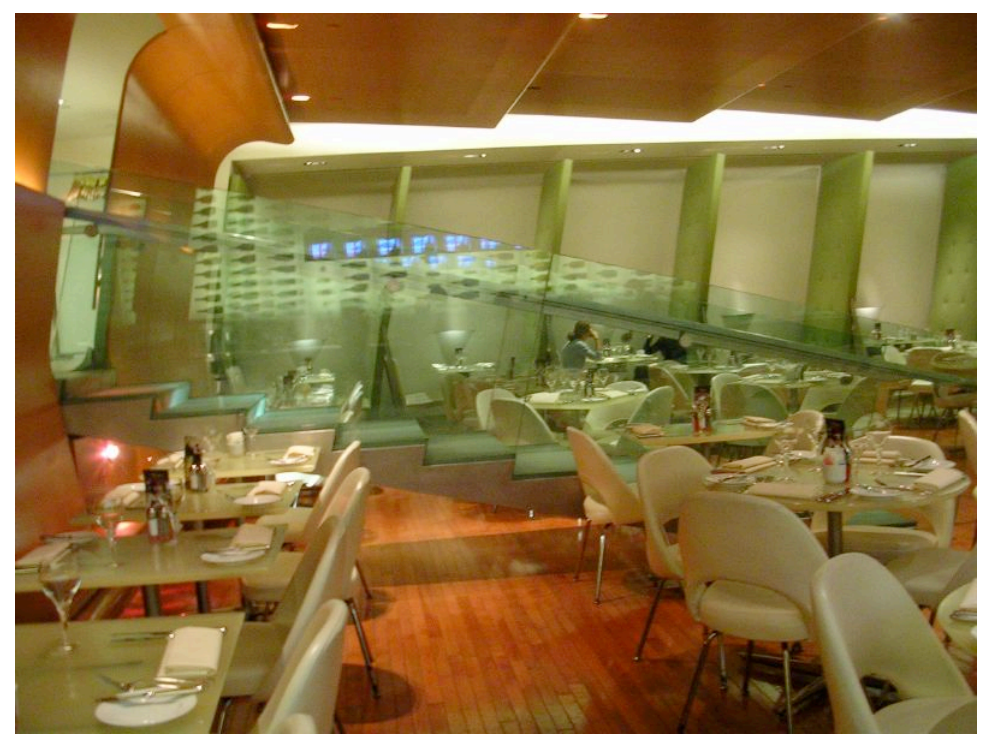

Fig. 5 Seagram brasserie by Diller and Scofidio. Photo by Karen Martin. 


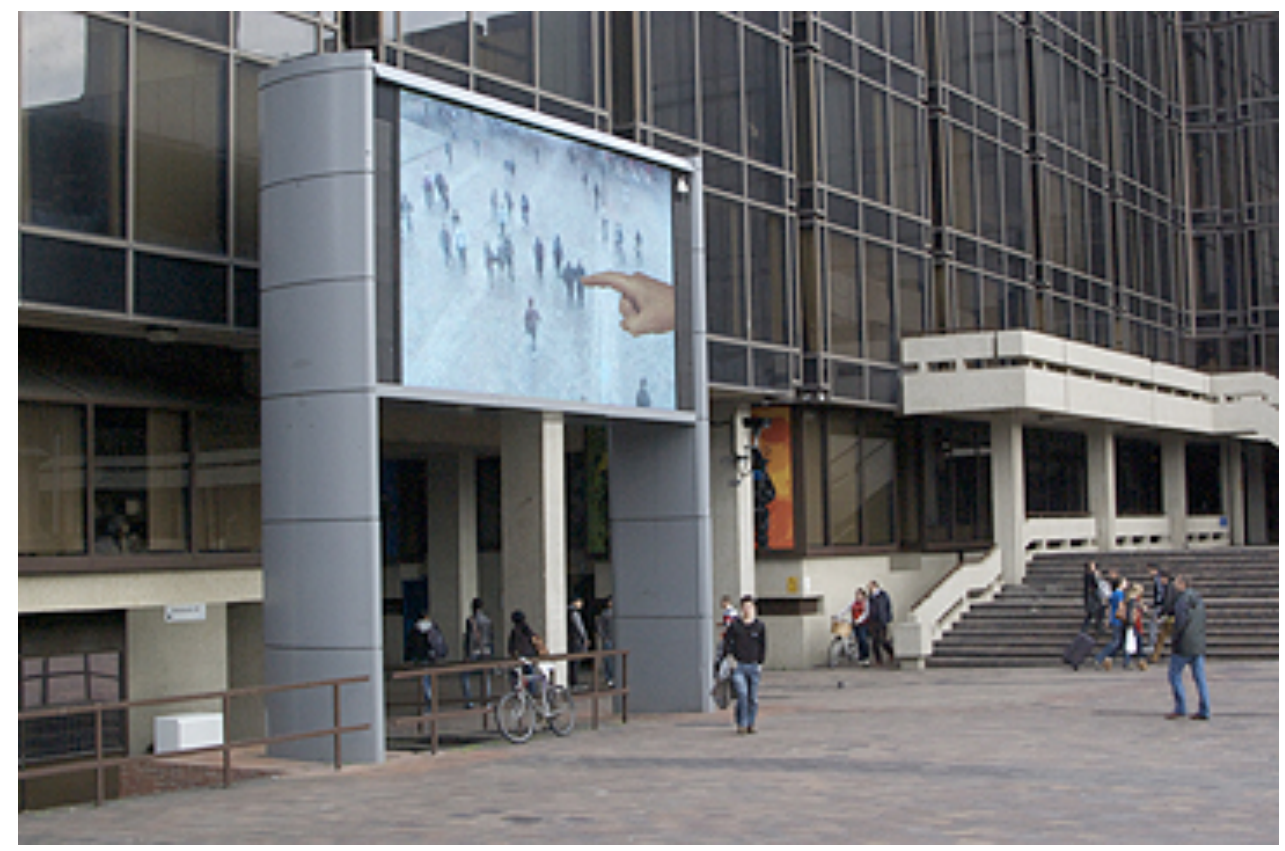

Fig. 6 Hand from Above by Chris O’Shea. Photo by Karen Martin. 


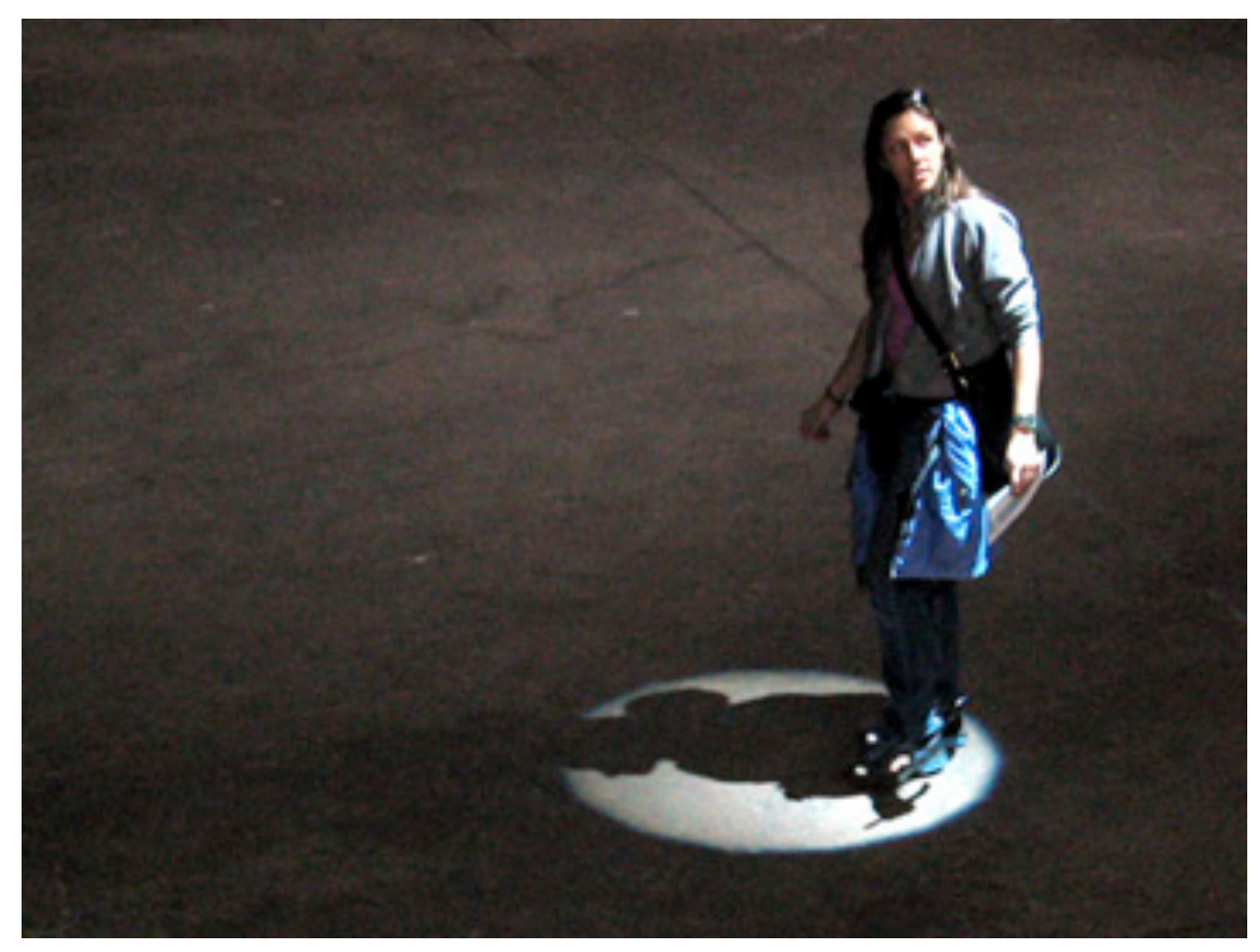

Fig. 7 ACCESS by Marie Sester. Photo from Flickr by rui guerra. 


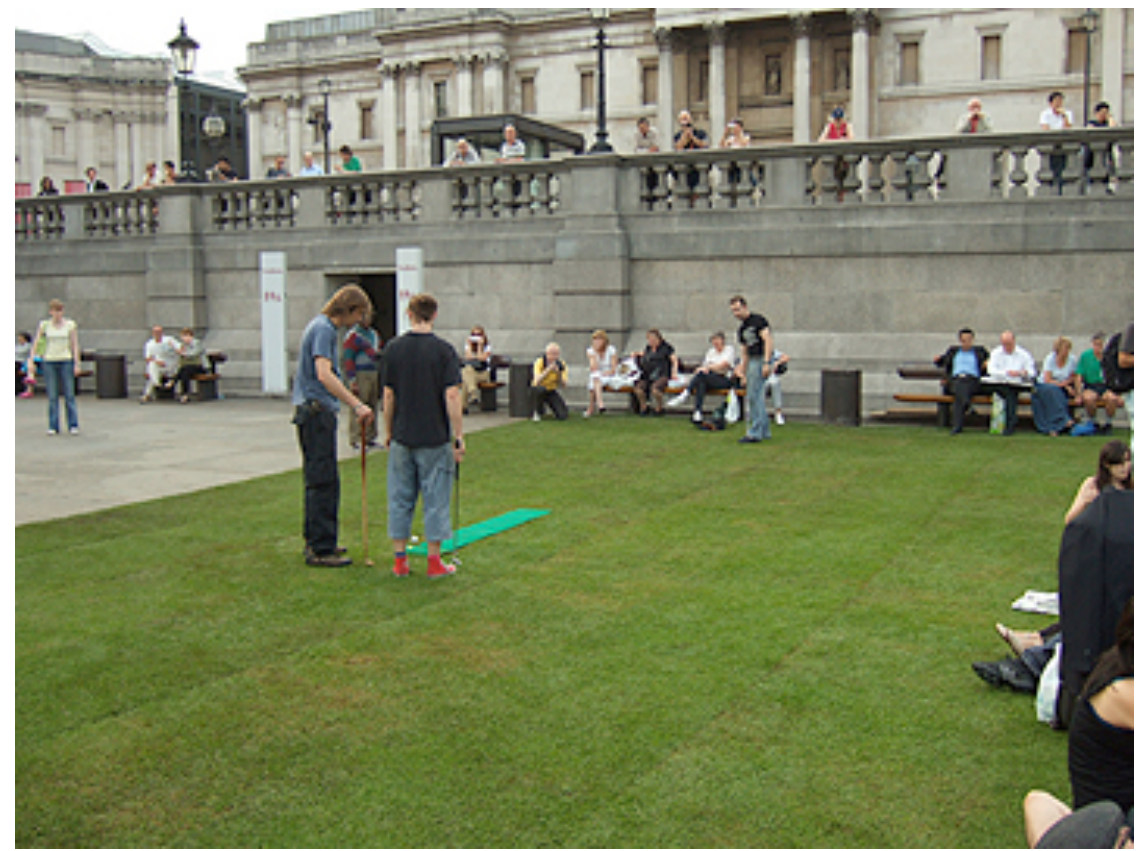

Fig. 8 Lawn in Trafalgar Square, BBC. Photo from Flickr by jaimelondonboy. 


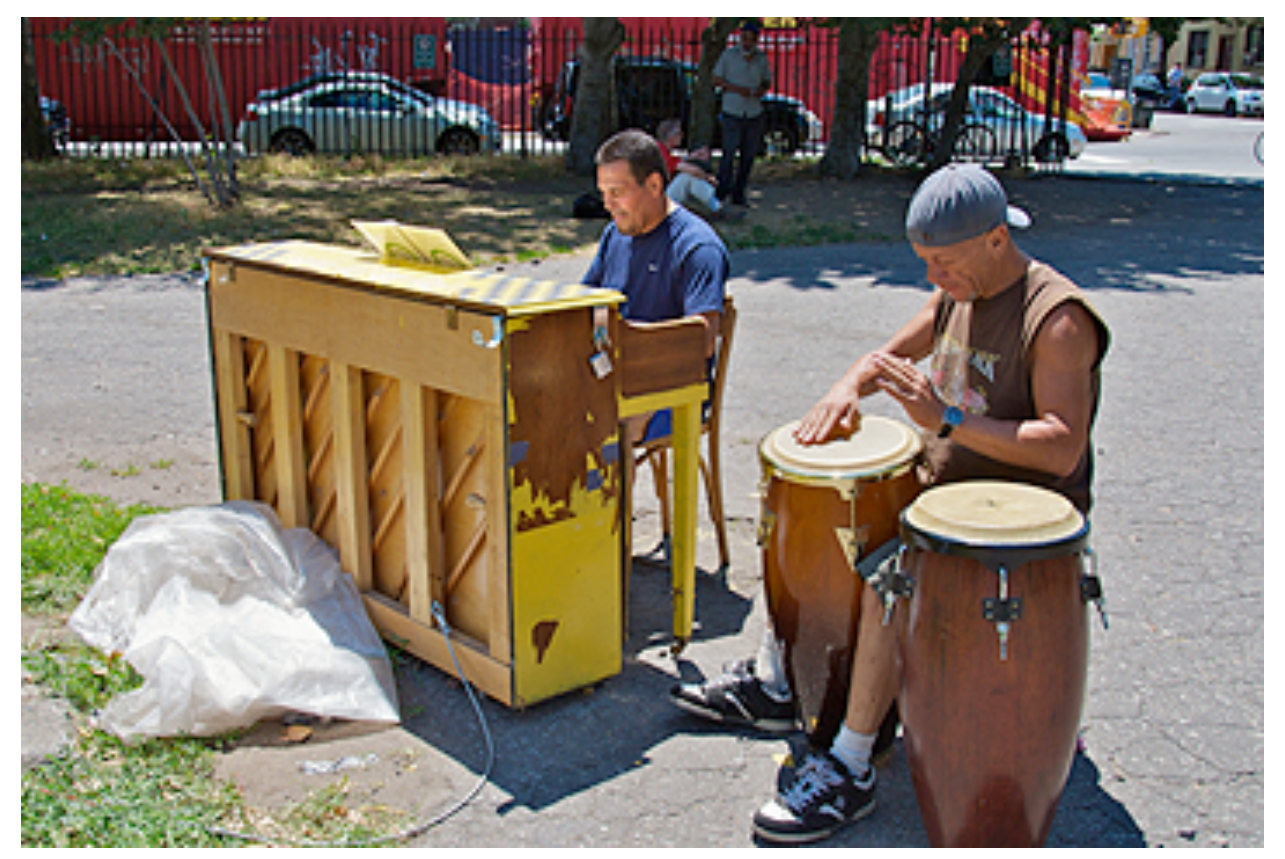

Fig. 9 Play Me I'm Yours by Luke Jerram. Photo from Flickr by Ed Yourdon. 


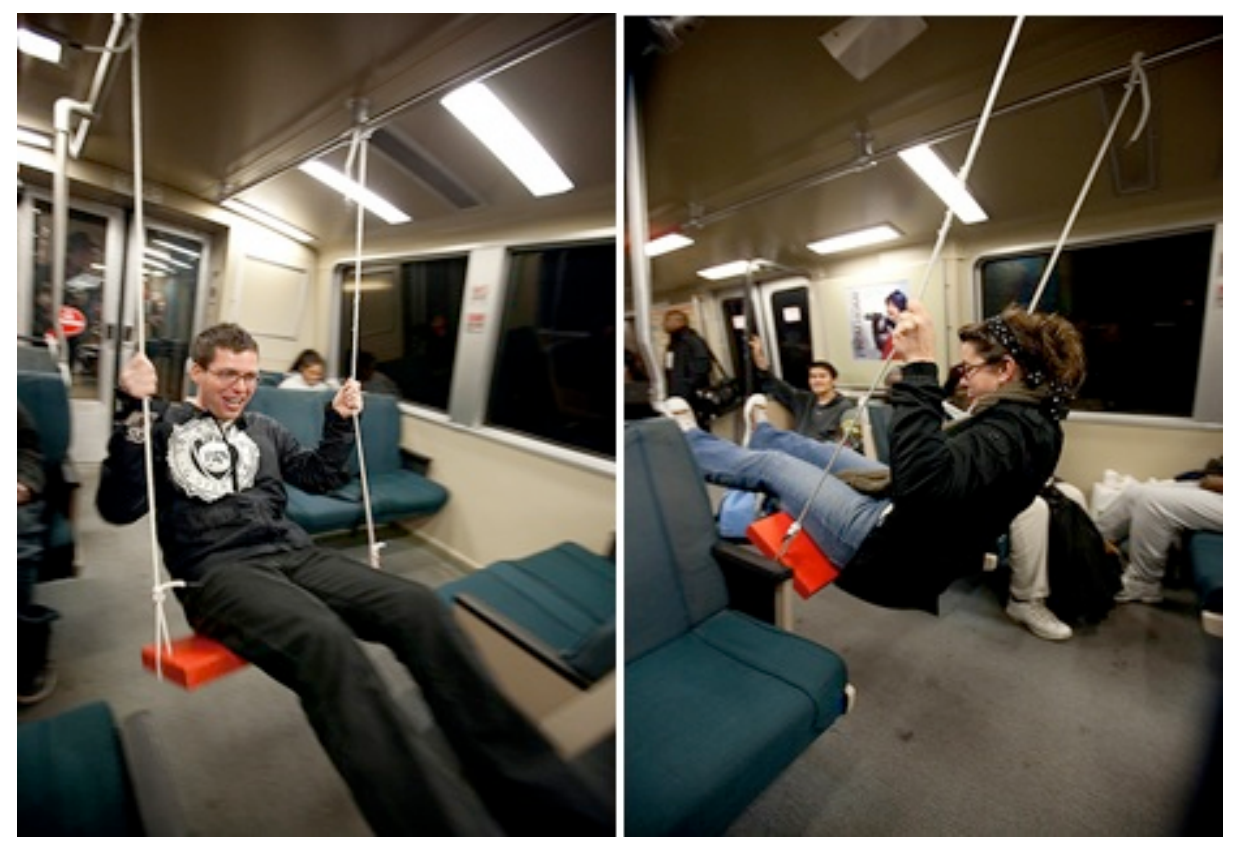

Fig. 10 Subway Swing by Caroline Woolerd. Photos from Flickr by neiltron. 


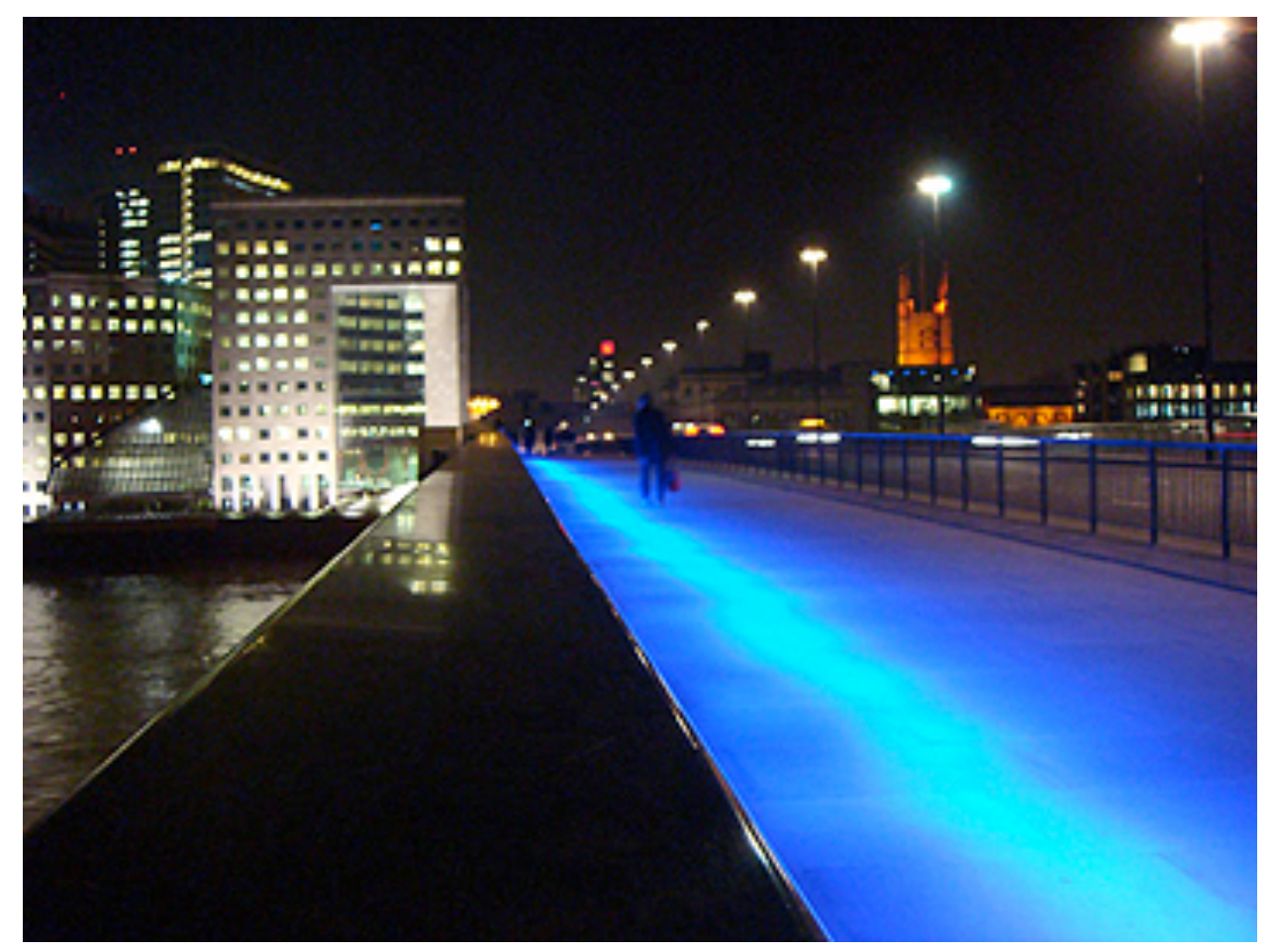

Fig. 11 North-South over East-West by Jason Bruges Architects. Photo from Flickr by steve.wilde. 


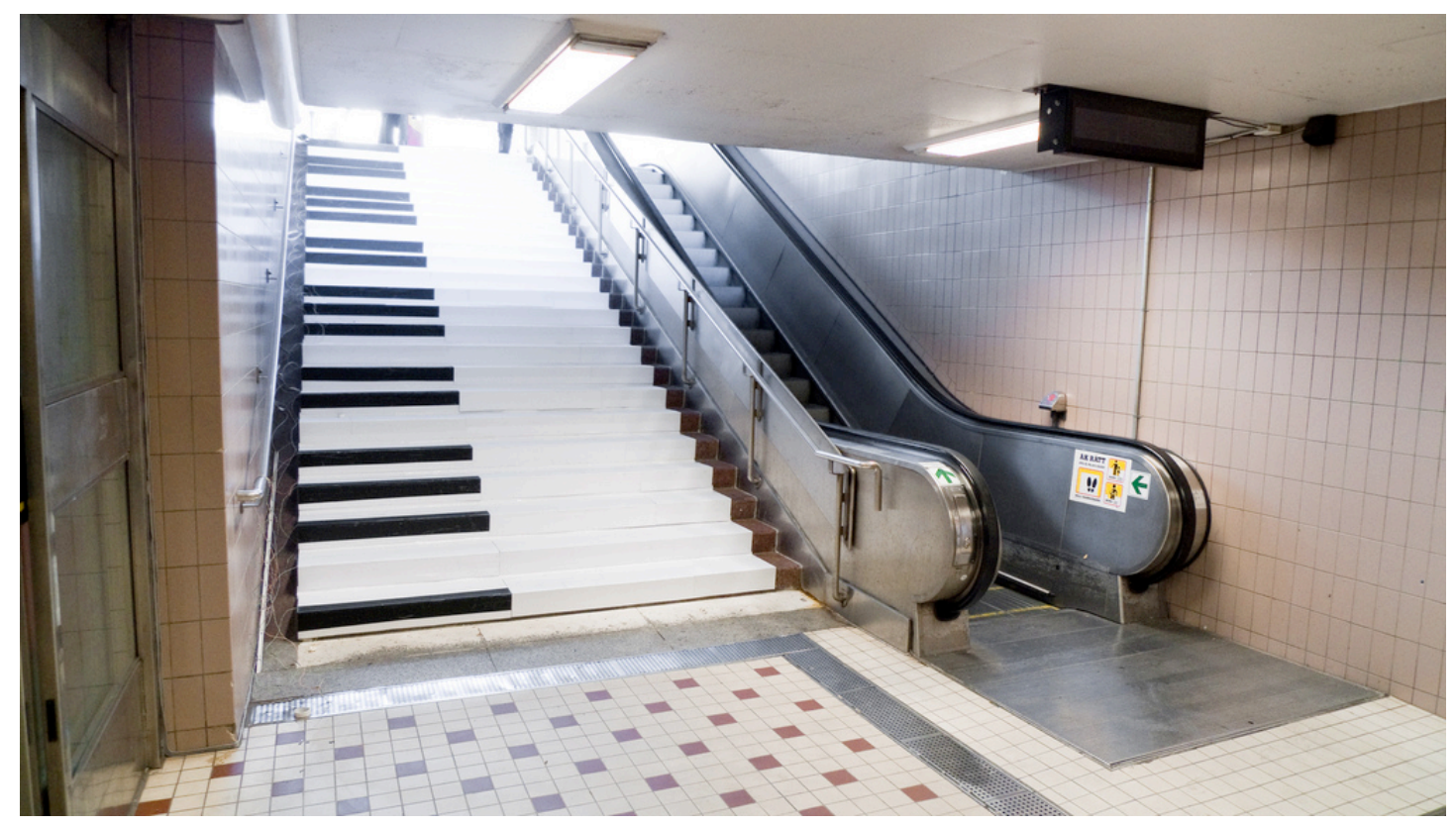

Fig. 12 Piano Stairs by DDB Stockholm. Photo from Flickr by kj.voglius. 